Eastern Illinois University

The Keep

Spring 2021

\title{
Trade Books' Contextualization of Consequential Women's Historical Significance
}

Toluwalase Solomon

Follow this and additional works at: https://thekeep.eiu.edu/lib_awards_2021_docs

Part of the Curriculum and Instruction Commons, and the Library and Information Science Commons

\section{Recommended Citation}

Solomon, Toluwalase, "Trade Books' Contextualization of Consequential Women's Historical Significance" (2021). 2021 Awards for Excellence in Student Research and Creative Activity - Documents. 4.

https://thekeep.eiu.edu/lib_awards_2021_docs/4

This Article is brought to you for free and open access by the 2021 Awards for Excellence in Student Research and Creative Activity at The Keep. It has been accepted for inclusion in 2021 Awards for Excellence in Student Research and Creative Activity - Documents by an authorized administrator of The Keep. For more information, please contact tabruns@eiu.edu. 
Trade Books' Contextualization of Consequential Women's Historical Significance

Abstract 


\section{Introduction}

As the $19^{\text {th }}$ Amendment's 100-year anniversary arrives, we report how one common curricular resource contextualizes important women oft-included in history curricula. Not an inquiry into historical quibbles about Feminists, this study explores how authors contextualize consequential female figures and trace the continuity-and-change within, between, and beyond eras. It is important for teachers of all grade levels to recognize how selected sources (mis)represent history.

Education initiatives prompt students to read, think, and communicate about ageappropriate sources in discipline-specific ways beginning in the earliest of grades and within all subjects (NCSS, 2010, 2013; NGA \& CCSSO, 2010). Students, for instance, are to engage with more nonfiction in English, reading, and language arts (subjects previously-synonymous with fiction) and analyze primary and secondary sources in history and social studies (disciplines

formerly-associated with textbooks) prior to articulating evidence-based understandings (Heafner \& Groce, 2007; McMurrer, 2008). Social studies teachers do not graze alone in the history pasture. Educational initiatives, however, do not provide curricular materials. Teachers, evershort on time, adjust sans guidance (Sapers, 2015). Common curricular resources have various limitations.

\section{Curricular Resources}

Teachers carefully select their classroom resources. Textbooks, primary sources, and trade books are common. Each has positive and problematic elements.

Textbooks are common but costly, comprehensive in scope but shallow in depth. Textbooks are replete with historical misrepresentations and, at times, self-censorship (e.g., Loewen, 2007; Matusevich, 2006; Miller, 2015; Roberts, 2015). Textbooks are limiting because 
their narrative, which often disregards diverse voices, does not invite interpretation from unconfident novices (Wineburg, 2001).

Primary sources provide readers a peephole into the past. Digital repositories, such as the Library of Congress, offer free access to a myriad of historical documents. Educators can abridge the length and amend the language of decades- or centuries-old informational texts written by and intended for adults (Wineburg \& Martin, 2009; Wineburg, Smith, \& Breakstone, 2012). Students, even young ones, can be trained to contextualize the era, scrutinize the source, and corroborate claims within primary sources (Bickford, 2013a; Nokes, 2011; Wineburg, 2001).

Trade books are common in classrooms (McMurrer, 2008). Trade books, unlike textbooks, are inexpensive, have engaging prose, and link English and language arts to social studies and history (LaDuke, Lindner, \& Yanoff, 2016; Heafner, 2018; Pace, 2012). Teachers can be selective as dozens, if not hundreds, of trade books cover many topics. Publishing companies detail books' reading levels for teachers to determine an appropriate reading level.

Trade books' positive attributes and ubiquity falsely suggest soundness; their historical accuracy and representation is uneven. Historical accuracy and representation are related, yet distinct. It is historically inaccurate to state Hitler brainwashed ordinary Germans; the euphemism conceals ordinary Germans' active complicity or passive acquiescence. It is historically misrepresentative to state Hitler's industrial genocide killed six million Jews, when the victims numbered more than 11 million (of which six million were Jewish). Both anecdotes appeared frequently within Holocaust-based trade books (Bickford et al., 2015). One cannot effectively predict the degree of misrepresentation within trade books. Christopher Columbus, Helen Keller, Rosa Parks, Anne Sullivan, Abraham Lincoln, Franklin Roosevelt, Thomas Jefferson, Native Americans' history and culture, slavery, Thanksgiving, the Holocaust, and civil 
rights were egregiously misrepresented (e.g., Bickford, 2013b, 2015, 2018a; Bickford \& Hunt, 2014; Bickford \& Knoechel, 2017; Bickford \& Lindsay, 2017; Bickford et al., 2019; Bickford \& Rich, 2014a, 2014b, 2015b; Bickford \& Schuette, 2016; Bickford et al., 2015; Bickford \& Silva, 2016; Schwebel, 2011). Historical misrepresentations were infrequent, though not absent, in books about Andrew Jackson, Amelia Earhart, Eleanor Roosevelt, European immigration, the Titanic, and child labor (Bickford \& Badal, 2017; Bickford, Dilley, \& Metz, 2015; Bickford \& Meier, 2017; Bickford \& Rich, 2014a, 2015a; Huwe, 2019; Sakowicz, 2016). Only a few dozen historical topics have been empirically reviewed.

Limitations appear in the aforementioned studies. First, many data pools mixed historical fiction with nonfiction. The former contains authorial liberties; the latter suggests accuracy. Extrapolation is complicated with mixed-genre data pools. Second, some inquiries conflated intended audience. Early grade students are learning to read and beginning to read to learn; middle grade students are learning disciplinary literacy. Children of different ages have different schemas. Findings are, arguably, confounded when age ranges are mingled. Finally, most content analyses centered on a singular person or era, not the larger context. Chattel slavery and civil rights, though separated by a century, are connected. To understand historical significance, students must grasp the antecedents and descendants. Many inquiries did not consider continuityand-change. The above limitations were mitigated in this inquiry. We explored how consequential women were historically contextualized. We included only nonfiction, scrutinized how the individual was contextualized, and contrasted early grade (K-4th grade) and middle grade (5-8th) books.

\section{Relevant Historical Research}


This investigation examined how trade book authors contextualize important women in history. It explores how dozens of biographies contextualize different women and represent continuity-and-change. This study figuratively maps a forest by examining individual trees.

The corpus of historical research, in its countless accents and discernments, framed the inquiry. Historians of the Women's Movement emphasize different events and figures but all agree that consequential women, such as Susan B. Anthony, Elizabeth Cady Stanton, and Lucretia Mott, both empowered and were empowered by ordinary citizens (e.g., Barry, 2000; Davis, 2008; Faulkner, 2011; Sigerman, 2001). Singular eras and advocacies—such as Seneca Falls Convention, $19^{\text {th }}$ Amendment, Equal Rights Amendment, and the right to control their body—are connected (e.g., Becker, 1981; DuBois, 1978; Feinberg, 1986; McMillen, 2008; Schoen, 2015; Tetault, 2014; Weiss, 2018). Tensions emerged whenever radical change confronted reactionary resistance (e.g., Hymowitz \& Weissman, 1978; Jones, 2007; Miles, 1989; Terborg-Penn, 1998).

Women's history can be organize into at least three eras. First-wave feminists in the $19^{\text {th }}$ and early- $20^{\text {th }}$ century sought civil liberties, such as voting and property rights; second-wave feminists of the 1960s and 1970s resisted what some characterized as de facto inequalities, such as socioeconomic equality, bodily integrity, and equitable familial responsibilities; third-wave feminism of the 1990s push(ed) intersectional initiatives (e.g., Duggan \& Hunter, 1995; Gerhard, 2001; Henry, 2004; Hewitt, 2010; Schoen, 2015). (A fourth-wave emerged in or around 2012 [Munro, 2013; Rivers, 2017], but biographies of key individuals are currently unavailable.) Throughout and within the eras, particular tactics and tensions transformed as battles of continuity-and-change remained. Reactionary resistances originated from husbands, fathers, elected officials, and peers, to mention a few, to combat radical transformation calls. Never 
achieving consensus, this fractious collection weighed societal, political, familial, and economic advocacies differently over the decades and centuries. Alliances, such as Stanton's and Anthony's National Woman Suffrage Association and Lucy Stone's American Woman Suffrage Association, collaborated and competed for prominence as tangential causes - such as temperance, abolitionism, pacifism—-blended initiatives.

History is emergent, unsettled ground. When exploring why voting privileges emerged first in the West, scholars emphasize — to differing degrees - (male) political initiatives to bring more women westward, (male) appreciation for frontier women's grueling contributions in the West, and Western women's agentive organization, as Beverly Beeton (1986) traced the historiographical clashes. This study explores if and how trade book authors contextualize the unsettled ground.

History, at times, manifests in fabricated fables and misguided memory. The 19th Amendment, ratified in 1920, did not guarantee women the right to vote; it articulated to states that being female could not, by itself, restrict voting privileges. Women of color, and male counterparts, remained disenfranchised. Curriculum often sanitizes seemingly unsavory details (Loewen, 2007; Roberts, 2015). Many feminist advocates were far from egalitarian; Elizabeth Cady Stanton, Alice Paul, and others promoted segregationist policies (e.g., Hymowitz \& Weissman, 1978; Jones, 2007; Terborg-Penn, 1998). The $19^{\text {th }}$ Amendment's radical change curbed (some) male political control but maintained white hegemony (Gordon, 2018). This study investigates how the women, their eras, and contemporaneous tensions- pleasant and unpleasant—are contextualized within trade books.

The inquiry has four presumptions. First, trade books can make history accessible for students bereft of prior knowledge. Second, trade books are imperfect and incomplete, yet 
expecting historians' detail is unrealistic. Third, sterilized stories do not substitute for history; children mature enough to study a topic should confront its tensions. Lastly, teachers - if aware of detailed, minimized, or disregarded elements — can supplement accordingly. This inquiry sought to explore how authors contextualized continuity-and-change and recognized the complexities and ignoble aspects as they established important women's — not simply Feminists—historical significance.

\section{Methods}

Rigorous qualitative research methods were utilized from data collection through analysis (Krippendorff, 2013; Maxwell, 2010; Zhang \& Wildemuth, 2009), which emulated comparable inquiries into textbooks (e.g. Loewen, 2007; Matusevich, 2006; Miller, 2015; Roberts, 2015) and trade books (e.g. Chick \& Corle, 2012; Chick, Slekar, \& Charles, 2010; Connolly, 2013; Eaton, 2006; Schmidt, 2013; Tschida et al., 2014). To determine the research pool, we developed a list of more than 300 potential women by exploring names within common textbooks and state social studies curricula. We searched literature-based, academic sites-MAS Ultra-School Edition and Novelist K-8 Plus—and widely-used teacher-based websites, such as Amazon, Barnes and Noble, Booksource, and Scholastic, to locate relevant trade books. To explore how authors contextualized these singular women and to juxtapose historical representation across grade range, only biographies targeting early grade and middle grade students were considered. ${ }^{1}$

Scholars have considered how context of publication shapes historical representation (e.g., Connolly, 2013; Eaton, 2006; Schmidt, 2013). As maintaining a class set of out-of-print books

\footnotetext{
${ }^{1}$ Data originated from Advantage/TASA (Touchstone Applied Science Associates) Open Standard, Lexile, Grade Level Expectations, and Developmental Reading Assessment. These leveled reading systems are each proprietary software reliant on a distinct algorithm to determine readability and text-complexity measuring, though weighing differently, word and sentence length, the number of words, letters, syllables, and syllable density for teachers to match books appropriate to students' ability.
} 
would be cumbersome for practicing teachers, only in-print books were considered. To avoid unnecessarily skewing the sample, no two books about the same woman were included.

Systematic sampling, the most appropriate form of sampling for our intents (Krippendorff, 2013), enabled the selection of a representative sample $(n=33 ; 10 \%)$ from the data pool $(n=331)$. Due to random-sampling, early grade $(n=12 ; 36 \%)$ and middle grade $(n=21 ; 64 \%)$ proportions of the data sample align with the data pool. The steps to establish a representative, random, and sizeable sample aligned with best practice methods (see Children's and Adolescent Literature Cited).

Content analysis included open and axial coding (Krippendorff, 2013). During open coding, two researchers separately scrutinized and recorded patterns and variances. This first reading enabled inspection of content included and excluded. We discussed observations and synthesized patterns into tentative, testable codes. During axial coding, we established the frequency and reliability of the codes by rereading each book individually and reevaluated the presence, degree of presence, or absence of content. As an adult writer could encode details a young reader might not decode, this second reading enabled determination of how content was included. We distinguished content that was explicitly detailed (ED) from content that was minimized or vague (MV) to an extent that readers might fail to fully grasp its import. A Likert scale of age-appropriate detail determined patterns within and between the early and middle grades (Bickford \& Lindsay, 2017). An early grades books with two or more sentences devoted specifically to a concept or a middle grades book with three or more was deemed ED. An early grades book with two or fewer sentences or in language a student this age might find unclear or a middle grades book required three or fewer was judged MV. When discrepancies emerged, 
researchers returned to the original texts to consider the efficacy behind the divergent interpretations. After the second rereading, no new patterns emerged (Appendix A).

\section{Findings}

Important patterns appeared in the randomly-selected data sample of early $(n=12 ; 36 \%)$ and middle $(n=21 ; 64 \%)$ grades books. The biographies established the historical significance of, yet struggled to contextualize, each figure. Children's and young adult authors largely crafted master narratives, which highlighted—but did not contextualize—each woman's successes overcoming specific obstacles (Demoiny \& Ferraras-Stone, 2018; Sakowicz, 2016). Key findings are reported and meaning is extracted.

The randomly-sampled books centered almost entirely on American women $(n=30$; 91\%). Fredrika Bremer, a Swedish writer and reformer, Frida Kahlo, a Mexican painter, and Sarah Winnemucca, a Northern Paiute activist (though she lived on seized land by the United States) were three notable exceptions. Focus and Features (Table 1) reveals data-based patterns about the highlighted figures and the general eras in which they advocated along with how the authors substantiated their claims. Books focusing on historically-significant women, as judged by their inclusion in state standards and common history textbooks, frequently focused on rich, white women who lived long ago.

Table 1

Focus and Features

\begin{tabular}{|c|c|c|c|c|}
\hline Focus & & Total & Early Grades & Middle Grades \\
\hline Focus & Rich White Woman & $17(52 \%)$ & $7(58 \%)$ & $10(48 \%)$ \\
\hline & Poor, White Woman & $5(15 \%)$ & $3(25 \%)$ & $2(9 \%)$ \\
\hline \multirow{2}{*}{ Era } & Woman of Color & $11(33 \%)$ & $2(17 \%)$ & $9(43 \%)$ \\
\hline & First* Wave & $22(67 \%)$ & $9(75 \%)$ & $13(62 \%)$ \\
\hline
\end{tabular}




\begin{tabular}{|c|c|c|c|}
\hline Second* Wave & $5(15 \%)$ & $2(17 \%)$ & $3(14 \%)$ \\
\hline Third* Wave & $6(18 \%)$ & $1(8 \%)$ & $5(24 \%)$ \\
\hline \multicolumn{4}{|c|}{ Integration of Primary Sources } \\
\hline Yes, throughout & $9(27 \%)$ & $2(17 \%)$ & $7(33 \%)$ \\
\hline Yes, limited & $4(12 \%)$ & $1(8 \%)$ & $3(14 \%)$ \\
\hline None & $20(61 \%)$ & $9(75 \%)$ & $11(53 \%)$ \\
\hline \multicolumn{4}{|c|}{$\begin{array}{l}\text { *Though this study was focused on consequential female figures, and not Feminists, the } \\
\text { Feminist history framework helps organize all women into general eras. First Wave denotes } \\
\text { women who lived in the } 19^{\text {th }} \text { and early- } 20^{\text {th }} \text { century; second-wave indicates women who } \\
\text { advocated in the mid- } 20^{\text {th }} \text { century; third-wave specifies late- } 20^{\text {th }} \text { and early } 21^{\text {st }} \text {-century } \\
\text { activists. }\end{array}$} \\
\hline
\end{tabular}

Race and social class appeared prominently as authors largely selected white, upper class women. Most of the randomly-selected books centered on white women, of which most were wealthy ( $n=17 / 22 ; 77 \%)$. No featured women of color were independently wealthy, which reveals more about American society through history than it does about trade book authors. Biographies of white women had balanced audiences, though books about women of color were nearly all intended for middle grade students. Race and class - oft-minimized in common curricula (e.g., Bickford \& Rich, 2014a; Bickford \& Schuette, 2016; Loewen, 2007; Roberts, 2015) — were whitewashed and erased, respectively, as white, privileged females were the neardefault. Past studies have demonstrated how non-white, economically-limited, sociallymarginalized citizens are overlooked (e.g., Bickford, 2018a; Bickford \& Rich, 2015a; Sakowicz, 2016).

Most books at all grade ranges centered on $19^{\text {th }}$ and early-20 $0^{\text {th }}$ century women. In this study, authors focused on distant, though important, figures whose $19^{\text {th }}$ and early- $20^{\text {th }}$ century advocacies are seemingly detached from modern issues. The above findings align to past studies about how both children's literature and biographies intended for children have historically transmitted citizenship lessons using female role models (Eaton, 2006; Schmidt, 2013). Modern 
women, whether of the $21^{\text {st }}$ or even mid-to-late- $20^{\text {th }}$ century women, were far less prominent, which obscures recent tensions and modern issues.

Authors rely on persuasive, accessible prose to engage the intended audience, but on evidence to substantiate claims. Few books integrated historical documents. Though it is not required, most did not include a single primary source. As most authors did not attempt to convince using evidence-based argumentation, readers are (implicitly) expected to comprehend the narrative. Past studies reported scant primary source integration in books intended for early and middle grade students (Bickford \& Badal, 2017; Bickford \& Lindsay, 2017; Bickford et al., 2019; Sakowicz, 2016).

The biographies, though, established these women's historical significance, a key historical thinking aspect (Seixas \& Morton, 2012). Data indicate these same biographies struggled to contextualize the women, another central historical thinking element. Contextualization, in which a person, item, or idea is properly situated, is a complex cognitive task that even young children do as they adjust speech to appropriate volumes as they enter the library or as they recognize that $x$ has different meanings in mathematics and English. To properly contextualize a historical figure, authors detail the era and contemporaneous tensions while considering continuity-and-change with preceding and succeeding eras and how comparable tensions have changed over time. This study, specifically, explored how authors contextualized the racial tensions manifest in gender-based advocacies. Contextualizing the Historical Figures and Tensions (Table 2) reports contextualization (or lack there of) patterns. Table 2

Contextualizing the Historical Figures and Tensions

$\begin{array}{lll}\begin{array}{l}\text { Contextualizing the } \\ \text { Historical Figure }\end{array} & \underline{\text { Contextualizing the }} \\ \text { Central Tensions } & \text { Contextualizing White Advocates' } \\ \text { Marginalization of Women of }\end{array}$




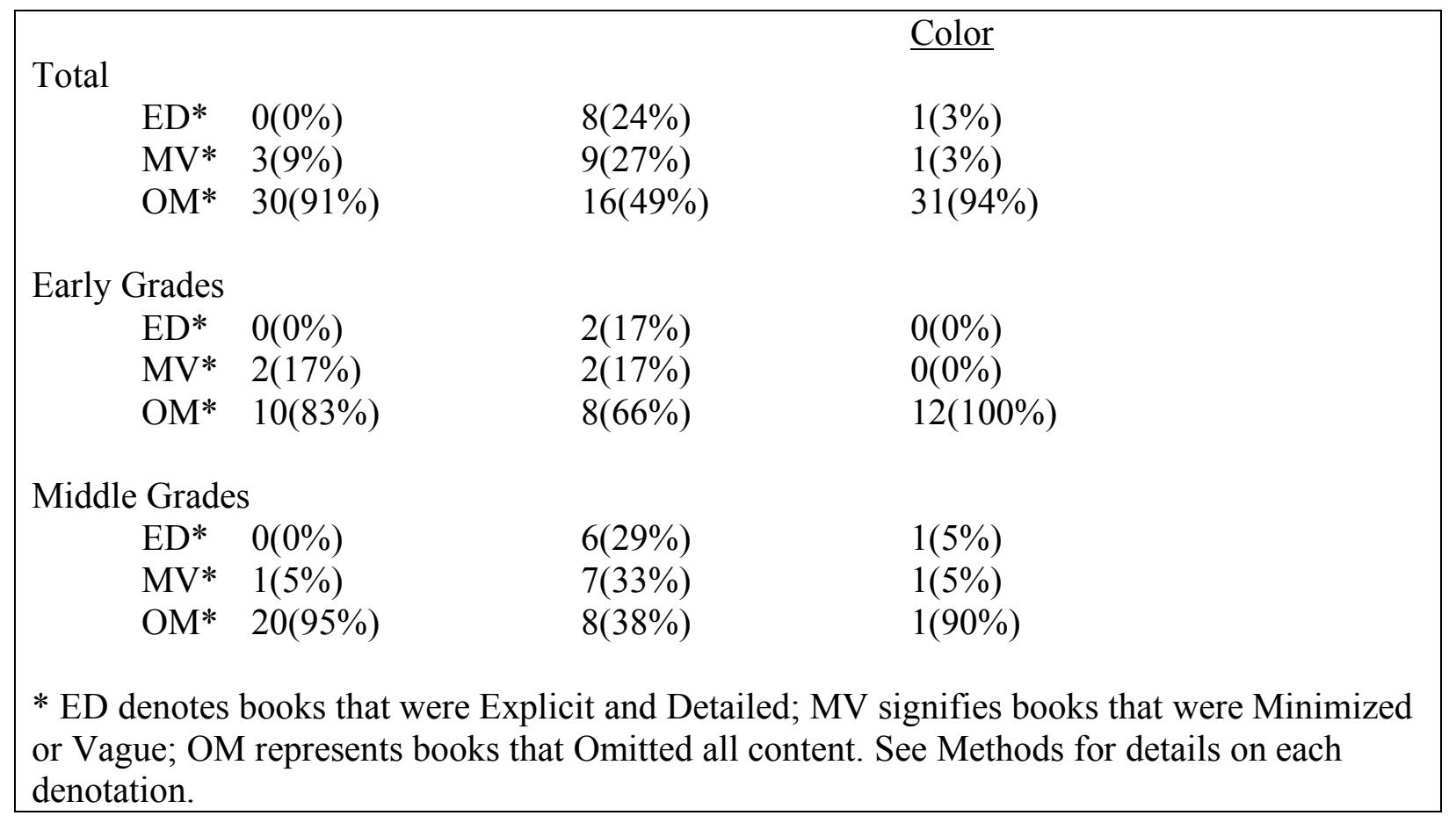

The biographies failed to contextualize these historically-significant women. As demonstrated in the first column, nearly all books disregarded elements of continuity-and-change with the preceding and succeeding eras for each figure. Decontextualization is common, though regrettable, within history-based trade books as, for instance, the Civil Rights Movement's resistance to segregation is rarely rooted in the remnants of chattel slavery (e.g., Bickford, 2015; Bickford \& Schuette, 2016; Connolly, 2013; Schwebel, 2011).

Authors identified, though struggled to contextualize, the contemporaneous tensions each figure experienced. Identification, unlike contextualization, is simple. All but one book (97\%) recognized two or more tensions in each figure's lived experiences. Tensions included specific (and often male) figures (e.g., family member or elected official), a civil right or tangible liberty (e.g., enfranchisement, property rights, reproductive control), or an intangible item, such as social and economic equality and bodily integrity. Few books, however, contextualized the tensions by noting antecedent and subsequent iterations. Comparable tensions, when 
acknowledged, appeared in a different region of the country though within the same era. This better contextualizes the tension, but fails to construct elements of continuity-and-change. Comparably, books about the Holocaust, child labor, and immigration aptly described the brutalities and degradations but also rarely situated them within a larger historical context (Bickford et al., 2015; Bickford \& Meier, 2017; Bickford \& Rich, 2015a).

In this sample, authors rarely constructed intersectionality within the narratives. The biographies largely disregarded the race-based tensions these women experienced, and some of whom initiated to bolster their social standing and socioeconomic position. Children's and young adult authors established white women's historical significance as being the default. A reader bereft of a robust historical schema would not likely recognize the absence of race. Authors articulated, at times, the racial and gender-based struggles of women of color, who were always distinguished as such. In doing so, women are white and as women of color are characterized with accompanying descriptors, such as African American woman or Mexican painter. Only a tiny portion of books explicitly $(n=2 ; 6 \%)$ or even vaguely $(n=3 ; 9 \%)$ articulated how certain historical events shaped the realities of both women of color and white women. Intersectionality was rare as white women were (implicitly) positioned to be the archetype and women of color were othered, or implicitly and negatively contrasted to the archetype. Othering appears often within curricular resources, such as appears within trade books centered on (non-hetero)sexuality and LGBTQ-based identity (Bickford, 2017, 2018b; Cart \& Jenkins, 2006; Day, 2000).

\section{Discussion}

Findings demonstrated each figure's historical significance was established, though not contextualized. On a timeline, each item represents a historically significant event but the sequential order illustrates the context. Adolf Hitler's spoken and written words might have 
fallen on deaf ears had the context—desperate post-war citizens struggling in an erratic economy in a land with a rich history of anti-Semitism — been different. Context matters as much as significance.

This research did not presume authors should incorporate every detail. Books intended for children and young adults cannot be accessible and comprehensive. Teachers, if aware, can mitigate the misrepresentations.

Primary sources, which are peepholes into the past, enable students to contextualize the central figure within the biographies. Binghamton University's Center for the Historical Study of Women and Gender has pages devoted to iconic African American women, militant Suffragists, and international advocates organized by continent. The US House of Representatives' History, Art, and Archives contains tabs guiding readers to explore the context, and continuity-andchange, with its Women in Congress online exhibit. The Library of Congress and National Archives each have more relevant sources and features than can be contained within this space. Students primary source analysis can assist interrogation of the selected biography by recognizing historical details they, previously, did not know existed.

To position students to recognize continuity-and-change, teachers can juxtapose their selected biography with mini-biographies of women with comparable experiences in distinct eras. Various compilations offer chapters for students to extract meaning. Cheryl Harness's (2003) Rabble Rousers: 20 Women Who Made A Difference, Margaret Chase Smith's and H. Paul Jeffers's (1968) Gallant Women, Jerry Aten's (1986) Women in History, Kendall Haven's (1995) Amazing American Women offer readers life stories about courageous American women. To many contemporaries, these women were unpopular (Susan B. Anthony), unconventional (Annie Sullivan), horrifying (Anne Hutchison), dangerous (Clara Barton), unwomanly (Elizabeth 
Blackwell), unusual (Amelia Earhart), or a meddler (Eleanor Roosevelt). Others appeared iconic (Harriet Tubman), popular (Dolly Madison,), and obscure (Frances Perkins, Doris Haddock). Henry Thomas's and Dana Lee Thomas's (1959) Living Biographies of Famous Women provides international complements-Cleopatra, Theodora, Joan of Arc, Mary Queen of Scots, Queen Christina, Madame de Maintenon, Charlotte Bronte, George Eliot, Elizabeth Barrett Browning, Florence Nightingale, Catherine Breshkovsky, Sarah Bernhardt, Ernestine Schumann-Heink, and Soong Mei-ling - to the oft-included American women. Students reading multiple chapters that each feature different women's experiences, accomplishments, and struggles, which juxtapose in important ways to the selected biography.

The above pathways are a starting point —not a comprehensive list of all possibilities — to help teachers fill the historical gaps. Educators should not remove imperfect books; no book is flawless. Teachers' awareness, though, is the crucial first step. Biographies not in the sample (see Children's and Adolescent Literature Cited) can be scrutinized (Appendix A) to identify the historical lacunae. 


\section{References}

Aten, J. (1986) Women in History. New York, NY: Good Apple.

Barry, K. (2000). Susan B. Anthony: A biography of a singular feminist. Bloomington, IN: Authorhouse.

Becker, S.D. (1981). The origins of the Equal Rights Amendment: American feminism between the wars. New York, NY: Greenwood Press.

Beeton, B. (1986). Women Vote in the West: the Woman Suffrage Movement 1869-1896. New York, NY: Garland Publishing.

Bickford, J. (2013a). Initiating historical thinking in elementary schools. Social Studies Research and Practice, 8(3), 60-77.

Bickford, J. (2013b). Examining historical (mis)representations of Christopher Columbus within children's literature. Social Studies Research \& Practice, 8(2), 1-24.

Bickford, J. (2015). Assessing and addressing the historical (mis)representations of the Civil Rights Movement within children's literature. The History Teacher, 48(4), 693-736.

Bickford, J. (2017). The representations of LGBTQ themes and individuals in non-fiction young adult literature. Social Studies Research and Practice, 12(2), 182-198.

Bickford, J. (2018a). Abraham Lincoln's historical representation in children's literature and young adult trade books. Social Studies Research and Practice, 13(2), 147-167.

Bickford, J. (2018b). Examining LGBTQ-based literature intended for primary and intermediate elementary students. The Elementary School Journal, 118(3), 409-425.

Bickford, J. \& Badal, T. (2017). Trade books' historical representation of Eleanor Roosevelt, First Lady of the World. Social Studies Research and Practice, 11(3), 1-18.

Bickford, J., Dilley, D., \& Metz, V. (2015). Historical writing, speaking, and listening using 
informational texts in elementary curricula. The Councilor: A Journal of the Social Studies, 76(1), 1-16.

Bickford, J. \& Hunt, L. (2014) Common Core, informational texts, and the historical (mis)representations of Native Americans within trade books. The Councilor: A Journal of the Social Studies, 75(2), 1-16.

Bickford, J. \& Lindsay, M. (2017) Franklin Delano Roosevelt's historical representation in children's and young adult literature. Social Studies Research and Practice, 12(2), 125138.

Bickford, J., Lindsay, M., \& Hendrickson, R. (2019). Trade books' evolving depictions of Thomas Jefferson, America's third president. Social Studies Research and Practice, 14(1), 40-63.

Bickford, J. \& Meier, S. (2017). Historical representation of immigration in intermediate elementary and middle grade trade books. The Councilor: A Journal of the Social Studies, 78(2), 1-18.

Bickford, J. \& Rich, C. (2014a). Trade books' historical representation of Eleanor Roosevelt, Rosa Parks, and Helen Keller. Social Studies Research \& Practice, 9(1), 18-65.

Bickford, J. \& Rich, C. (2014b). Examining the representations of slavery within children's literature. Social Studies Research \& Practice, 9(1), 66-94.

Bickford, J. \& Rich, C. (2015a). Scrutinizing and supplementing children's literature about child labor. Social Studies Research and Practice, 10(1), 21-40.

Bickford, J., \& Rich, C. (2015b). The historical representation of Thanksgiving within primaryand intermediate-level children's literature. Journal of Children's Literature, 40(2), 5-21.

Bickford, J. \& Schuette, L. (2016). Trade books' historical representation of the Black Freedom 
Movement, slavery through Civil Rights. Journal of Children's Literature, 41(1), 20-43.

Bickford, J., Schuette, L., \& Rich, C. (2015). Examining the historical representation of the Holocaust within trade books. Journal of International Social Studies, 5(1), 4-50.

Booksource. Retrieved from http://www.booksource.com/

Cart, M. \& Jenkins, C. (2006). The heart has its reasons: Young adult literature with gay/lesbian/queer content, 1969-2004. Lanham, MD: Scarecrow Press.

Chase Smith, M. \& Jeffers, H.P. (1968) Gallant Women New York, NY: McGraw-Hill.

Chick, K., \& Corle, S. (2012). A gender analysis of NCSS Notable Trade Books for the intermediate grades. Social Studies Research and Practice, 7(2), 1-14.

Chick, K., Slekar, T., \& Charles, E. (2010). A gender analysis of NCSS Notable picture book winners: 2006-2008. Social Studies Research and Practice, 5(3), 21-31.

Connolly, P. (2013). Slavery in American children's literature, 1790-2010. Iowa City, IA: University of Iowa Press.

Davis, S. (2008). The political thought of Elizabeth Cady Stanton: Women's rights and the American political traditions. New York, NY: New York University Press.

Day, F.A. (2000). Lesbian and gay voices: An annotated bibliography and guide to literature for children and young adults. Westport, CT: Greenwood Press.

Demoiny, S. B. \& Ferraras-Stone, J. (2018). Critical literacy in elementary social studies: Juxtaposing historical master and counter narratives in picture books. The Social Studies, 109(2), 64-73.

DuBois, E. (1978). Feminism and Suffrage: The emergence of an independent women's movement in the U.S., 1848-1869. Ithaca, NY: Cornell University Press.

Duggan, L. \& Hunter, N.D. (1995). Sex wars: Sexual dissent and political culture. New York, 
NY: Routledge Press.

Eaton, G. (2006). Well-dressed role models: The portrayal of women in biographies for children. Lanham, MD: Scarecrow Press.

Faulkner, C. (2011). Lucretia Mott's heresy: Abolition and women's rights in nineteenth-century America. Philadelphia, PA: University of Pennsylvania Press.

Feinberg, R. (1986). The Equal Rights Amendment: An Annotated bibliography of the issues, 1976-1985. New York, NY: Greenwood Press.

Gerhard, J.F. (2001). Desiring revolution: second-wave feminism and the rewriting of American sexual thought, 1920 to 1982. New York: Columbia University Press.

Gordon, A.D. (2018, August 27). How to Celebrate a Complicated Win for Women. New York Times. Retrieved from https://www.nytimes.com/2018/08/27/opinion/how-to-celebrate-acomplicated-win-for-women. html action $=$ click\&module=RelatedLinks\&pgtype=Article

Harness, C. (2003). Rabble Rousers: 20 Women Who Made A Difference. New York, NY: Dutton Children's Books.

Haven, K. (1995). Amazing American Women . New York, NY: Libraries Unlimited.

Heafner, T.L. (2018) Elementary ELA/social studies integration: Challenges and limitations. The Social Studies, 109(1), 1-12.

Heafner, T.L., \& Groce, E. (2007). Advocating for social studies: Documenting the dfeecline and doing something about it. Social Education, 71(5), 255.

Henry, A. (2004). Not my mother's sister: Generational conflict and third-wave feminism. Bloomington, IN: Indiana University Press.

Hewitt, N. (Ed.) (2010). No permanent waves: Recasting histories of U.S. feminism. New Brunswick, NJ: Rutgers University Press. 
Huwe, C. (2019). Representation of the Titanic in Children's Literature. The Councilor: A Journal of the Social Studies, 80(1), 1-38.

Hymowitz, C. \& Weissman, M.E. (1978). A history of women in America. New York, NY: Bantam Books.

Jones, M.S. (2007). All bound up together: The woman question in African American public culture, 1830-1900. Chapel Hill, NC: University of North Carolina Press.

Kerr, A.M. (1992). Lucy Stone: Speaking out for equality . New Brunswick, NJ: Rutgers University Press.

Krippendorff, K. (2013). Content analysis: An introduction to its methodology, Third Edition. Washington, DC: Sage.

LaDuke, A., Lindner, M., \& Yanoff, E. (2016). Content, disciplinary, and critical literacies in the C3 and Common Core. Social Studies Research and Practice, 11(3), 96-111.

Library of Congress. Retrieved from http://www.loc.gov/

Loewen, J. (2007). Lies my teacher told me: Everything your American history textbook got wrong. New York: Simon and Schuster.

Matusevich, M. (2006). Strange bedfellows: Censorship and history textbooks. Social Studies Research and Practice, 1(3), 359-373.

Maxwell, J. (2010). Using numbers in qualitative research. Qualitative Inquiry, 16(6), 475-482.

McMillen, S.G. (2008). Seneca Falls and the origins of the women's rights movement. New York, NY: Oxford University Press.

McMurrer, J. (2008). Instructional time in elementary schools: A closer look at changes for specific subjects. Washington, D.C.: Center on Education Policy.

Miles, R. (1989). The women's history of the world. New York, NY: Harper \& Row. 
Miller, J. (2015). Never a fight of woman against man: What textbooks don't say about

Women's Suffrage. The History Teacher, 48(3), 437-482.

Munro, E. (2013). Feminism: A Fourth Wave? Political Insight, 4(2), 22-25.

National Council for the Social Studies (NCSS) (2010). National curriculum standards for social studies: A framework for teaching, learning, and assessment. Silver Spring, MD: Library of Congress.

National Council for the Social Studies (2013). College, career, and civic life (C3) framework for social studies state standards: Guidance for enhancing the rigor of $k-12$ civics, economics, geography, and history. Silver Spring, MD: NCSS.

National Governors Association Center for Best Practices \& Council of Chief State School Officers. (2010). Common Core State Standards for English language arts and literacy in history/social studies, science, and technical subjects. Washington, DC: Authors.

Nokes, J. (2011). Recognizing and addressing the barriers to adolescents" "reading like historians." The History Teacher, 44(3), 379-404.

Pace, (2012). Teaching literacy through social studies under No Child Left Behind. Journal of Social Studies Research, 36(4), 329-358.

Rivers, N. (2017). Postfeminism(s) and the arrival of the fourth wave. New York, NY: Palgrave Macmillan.

Roberts, S. (2015). A review of social studies textbook content since 2002. Social Studies Research and Practice, 9(3), 51-65.

Sakowicz, S.K. (2016). Researching the historical representations of Andrew Jackson in trade books. Social Studies Research and Practice, 11(2), 33-50.

Sapers, J. (2015 February 26). Common Core's unintended consequences? More teachers write 
their own curricula. The Hechinger Report: Covering Innovation and Inequality in Education. Retrieved from http://hechingerreport.org/common-cores-unintendedconsequence/

Schmidt, G. (2013). Making Americans: Children's literature from 1930-1960. Iowa City, IA: University of Iowa Press.

Schoen, J. (2015). Abortion after Roe. Chapel Hill, NC: University of North Carolina Press.

Scholastic. Retrieved from www.scholastic.com/teachers/

Schwebel, S. (2011). Child-sized history: Fictions of the past in U.S. classrooms. Nashville, TN: Vanderbilt University Press.

Seixas, P. \& Morton, T. (2012). The big six historical thinking concepts. Toronto, Ontario: Nelson College Indigenous.

Sigerman, H. (2001). Elizabeth Cady Stanton: The right is ours. New York, NY: Oxford University Press.

Terborg-Penn, R. (1998). African American women in the struggle for the vote, 1850-1920. Bloomington, IN: Indiana University Press.

Tetault, L. (2014). The myth of Seneca Falls: Memory and the women's suffrage movement, 1848-1898. Chapel Hill: The University of North Carolina Press.

Thomas, H. \& Thomas, D.L. (1959). Living biographies of famous women. New York, NY: Garden City Publishing.

Tschida, C., Ryan, C., \& Ticknor, A. (2014). Building on windows and mirrors: Encouraging the disruption of "single stories" through children's literature. Journal of Children's Literature, 40(1), 28-39.

Weiss, E.F. (2018). The woman's hour: The great fight to win the vote. New York, NY: Viking 
Press.

Wineburg, S. (2001). Historical thinking and other unnatural acts: Charting the future of teaching the past. Philadelphia, PA: Temple University Press.

Wineburg, S., \& Martin, D. (2009). Tampering with history: Adapting primary sources for struggling readers. Social Education, 73(5), 212-216.

Wineburg, S., Smith, M., \& Breakstone, J. (2012). New directions in assessment: Using Library of Congress sources to assess historical understanding. Social Education, 76(6), 290293.

Zhang, Y., \& Wildemuth, B. (2009). Qualitative analysis of content. In B. Wildemuth (Ed.) Applications of Social Research Methods to Questions in Information and Library Science (pp.308-319). Westport, CT: Libraries Unlimited.

\section{Children's and Adolescent Literature Cited}

Alexander, H. (2016). Who is Hillary Clinton? New York, NY: Grosset \& Dunlap.

Blau, J. (1990). Betty Friedan: Feminist American women of achievement. New York, NY: 